\title{
THEORIZING HUMAN ADAPTATION TO CLIMATE CHANGE FROM AN INTERNATIONAL BIOETHICAL AND BIOLEGAL PERSPECTIVE
}

\author{
Simona Fanni ${ }^{1}$, Ernani Contipelli ${ }^{2}$
}

\begin{abstract}
In 2012, Dr. Liao, Dr. Sandberg and Dr. Roache published an interesting research, aimed at suggesting a challenging solution to climate change based on genetic manipulation: smaller human beings would individually suit better environmental challenges. Although appealing, this theory quite soon reveals its weaknesses against a legal and bioethical landscape, as it would evidently clash with human rights and the principles of international bioethics and international biolaw. Drawing inspiration from the above-mentioned research, this paper assesses the interplay between climate change and bioethical and legal implications under international law. In this respect, the horizons of genome editing are considered against the background of the relevant international reference tools, as the UNESCO Universal Declaration on Human Genome and Human Rights and the Oviedo Convention, for advancing feasible solutions offered by therapeutic interventions on human somatic cells and epigenetics as means for improving human adaptation to the adverse effects of climate change.
\end{abstract}

Keywords: Adaptation to climate change - Genome editing - Human germline alterations - UNESCO Universal Declaration on Human Genome and Human Rights Oviedo Convention - Therapeutic interventions on human somatic cells - Epigenetics Epigenetic-based diagnostic, preventive and therapeutic strategies - Right to enjoy the benefits of scientific progress

\section{INTRODUCTION}

In 2012, Dr. Liao, Dr. Sandberg and Dr. Roache published an interesting research, aimed at suggesting an innovative - and challenging - solution to climate change based on genetic manipulation on future generations: smaller human beings would individually suit better environmental challenges and would make up a more eco-friendly society. The study also advanced several other solutions, capable of affecting personal life from different viewpoints, as administering pharmaceutical therapies in order to influence people's preference about food, lowering birth-rates through cognitive enhancement,

\footnotetext{
${ }^{1} \mathrm{PhD}$ Candidate in Legal Sciences, with a specialization in International Law and European Union Law, at the University of Cagliari, Doctoral School in Legal Sciences.

${ }^{2}$ PhD Public Law PUC/SP (Brazil). Professor University of UNOCHAPECO (Brazil)
} 
pharmacological enhancement of altruism and empathy, but genetic engineering was the core of the proposal elaborated. ${ }^{3}$

The study by Dr. Liao, Dr. Sandberg and Dr. Roache has offered the precious baseline for the reflections advanced in the present paper. Their theory is very appealing but, when closer analysis is made, it turns out to clash with some fundamental principles and rules of international human rights law and international bioethics and biolaw, as human dignity, genetic identity and self-determination, especially as far as it concerns personal choices related to health and private life. ${ }^{4}$

This paper firstly assesses the most relevant international instruments that address bioengineering and in particular genome editing in order to conceptualize and frame the main issues at stake from a biolegal and human rights-based perspective. In particular, the UNESCO Universal Declaration on Human Genome and Human Rights and the Council of Europe's Convention on Human Rights and Biomedicine represent the focus of the analysis, for the purpose of identifying the feasible scientific practices under international law and bioethics. Once that ethical applications of genome editing and epigenetics are identified as the viable and promising paths allowed in the international framework, this study surveys the existing human rights landscape, to the end of elucidating States' duties aimed at protecting human beings from the adverse effects of climate change. More in detail, specific instruments are suggested as the legal bases for developing a human rights-based approach capable of providing accommodation for ethically admissible bioengineering and epigenetics. From this perspective, human dignity is taken into consideration as the founding and transcendental value that underlies the analysis, for suggesting the existence of States' obligations arising from the right to health and the right to science as means for ensuring adequate protection to individuals against the adverse effects of climate change, by postulating the promotion of human adaptation through human rights enforcement as a component of States' policies. Furthermore, environmental justice and solidarity are taken into consideration as a means for promoting equity in favour of disadvantaged categories. In this respect, access to advanced bioengineering and epigenetics interventions is suggested as a feature of the enjoyment of the right to health and the right to science, even if mainstreaming is still recognized as non-immediately feasible solution on a large-scale. This approach is also advanced as appropriate path to promote justiciability of human rights violations related to the adverse effects of climate change, in a context where judicial protection has been a major difficulty and a strong shortcoming.

\footnotetext{
3 LIAO, M., SANDBERG, A., ROACHE, R., 'Human Engineering and Climate Change', 2012. Forthcoming as a Target Article in Ethics, Policy and the Environment, available at http://www.smatthewliao.com/wp-content/uploads/2012/02/HEandClimateChange.pdf last accessed 7 October 2017.

4 MARKS, S. P., "Tying Prometheus Down: the International Law of Human Genetic Manipulation”, Chicago Journal of International Law 3 (1), 2002, pp. 115-136.
} 


\section{CLIMATE CHANGE AND HUMAN RIGHTS IN INTERNATIONAL LAW: FRAMING STATES' DUTIES}

Climate change has become an urgent concern for the international community, which cannot be delayed in the global agenda. The rate at which some unequivocal symptoms have increased is a clear caveat that a dramatic shift is necessary, as for example global temperature raise of about $1.1^{\circ}$ Celsius since the late Nineteenth Century, that mainly concentrated in the last thirty-five years. Again, evident signs that we passed the line come from warming and acidifying oceans, sea level rise, declining Arctic Sea ice, shrinking ice sheet, decreased snow cover, glacial retreat and extreme events like the recent devastating hurricane Irma. ${ }^{5}$

The international community has repeatedly tried to give an appropriate conventional response to the challenges posed by climate change, and these efforts, in the early Nineties, have led to the United Nations Framework Convention on Climate Change $^{6}$ for the purpose of curbing global temperature increases, which was complemented, few years later, in 1997, by the Kyoto Protocol ${ }^{7}$ on greenhouse emissions, that entered into force only in 2005. Awareness that concerted action is necessary without delay matured in the international community since from the Seventies when, at the Conference of Stockholm, also under the pressure of non-governmental organizations (NGOs) and civil society, States began to set the spotlight on our world and the need for joint intervention to fight climate change.

The recognition of the interrelationship between climate change and human rights is a fundamental feature of the globally concerted approach undertaken by the international community. ${ }^{8}$ This acknowledgment was restated many times, on the

\footnotetext{
5 "The Impact of Climate Change on Natural Disasters", Earth Observatory, NASA, available at https://earthobservatory.nasa.gov/Features/RisingCost/rising cost5.php last accessed 16 October 2017. VIDAS, D., "The Earth in the Anthropocene and the World in the Holocene?", ESIL Reflections, 24 August 2015, 4(6), available at http://www.esil-sedi.eu/node/987 last accessed 6 October 2017. For deeper analysis of biotechnological risks affecting human security and of environmental risks, see CORTI VARELA, J. L., "Seguridad Humana ante nuevos riesgos biotecnológicos: entre la "cientificación" y la "politización"”, Araucaria. Revista Iberoamericana de Filosofia, Política y Humanidades, n 36, 2016, pp. 417-437.

6 UN General Assembly, United Nations Framework Convention on Climate Change: resolution/adopted by the General Assembly, 20 January 1994, A/RES/48/189, available at https://unfccc.int/resource/docs/convkp/conveng.pdf last accessed 13 October 2017.

Kyoto Protocol to the United Nations Framework Convention on Climate Change, UN Doc FCCC/CP/1997/7/Add.1, 10 December 1997; 37 ILM 22 (1998), available at https://treaties.un.org/pages/ViewDetails.aspx?src=IND\&mtdsg no=XXVII-7-a\&chapter=27\&lang=en last accessed 12 October 2017.

8 GARCÍA SAN JOSÉ, D. I., Crisis económica, vulnerabilidad multidimensional y cambio climático: la "tormenta perfecta" para el derecho a la salud en europa, Bioderecho.es, Estudios de Vulnerabilidad, n. 5, 2017, available at http://revistas.um.es/bioderecho/article/view/290821 last accessed 10 October 2017; SÁNCHEZ PATRÓN, J. M., TORRES CAZORLA, M.I., GARCÍA SAN JOSÉ, D., Bioderecho, Seguridad y Medioambiente. Biolaw, Security and Environment, Tirant Lo Blanch, Valencia,
} 
occasion of the Habitat Conferences, ${ }^{9}$ in Habitat Agenda $^{10}$ and the UN Millennium Declaration ${ }^{11}$ and is enshrined in numerous Resolutions adopted by the framework of the United Nations by the Human Rights Council since the 2000, as the Resolution $7 / 23,{ }^{12}$ Resolution 10/4, ${ }^{13}$ Resolutions $18 / 22,{ }^{14} 26 / 27^{15}$ and $29 / 15,{ }^{16}$ and recently adopted Resolution $32 / 33 .{ }^{17}$

Almost one year ago, on 4 November 2016, the international community welcomed the entry into force of the Paris Agreement, ${ }^{18}$ which promises to be an innovative instrument capable of finally filling the gaps of the tools previously adopted, by bridging the diverging position of States and suiting the claims of non-State actors who invoked a drastic change in the management of the climate emergency that is affecting the Earth. The formula adopted by the Paris Agreement seems successful:

2015; STILLINGS, Z. L., "Human Rights and the New Reality of Climate Change: Adaptation's Limitations in Achieving Climate Justice", Michigan Journal of International Law, $\mathrm{n}^{\circ}$ 35(3), 2014, pp. 638-671. Also see: McADAM, J., "Part IV, Living with climate change and climate change adaptation measures - CH. 23 Climate change and related displacement of persons" in CARLARNE, C.P., GRAY, K.R., TARASOFSKY, R., (eds.), Oxford Handbook of International Climate Change Law, Oxford University Press, Oxford, 2016.

9 For further information on UN Habitat Conferences, see the Official Website at https://unhabitat.org/habitat-iii-conference/.

10 "The Habitat Agenda Goals and Principles, Commitments and the Global Plan of Action" is available at http://www.un.org/en/events/pastevents/pdfs/habitat agenda.pdf, last accessed 15 October 2017.

11 UN General Assembly Resolution 55/2, United Nations Millennium Declaration, A/55/L.2, available at http://www.un.org/millennium/declaration/ares552e.htm last accessed 15 October 2017.

12 UN Human Rights Council, Resolution 7/23 on Human Rights and Climate Change, A/HRC/RES/7/23, available at http://ap.ohchr.org/documents/E/HRC/resolutions/A_HRC_RES 7 23.pdf last accessed 12 October 2017.

13 UN Human Rights Council, Resolution 10/4, Human Rights and Climate Change, A/HRC/RES/10/4, available at http://ap.ohchr.org/documents/E/HRC/resolutions/A HRC RES 10 4.pdf last accessed 13 October 2017.

14 UN Human Rights Council, Resolution 18/22, Human Rights and Climate Change, $\mathrm{A} / \mathrm{HRC} / \mathrm{RES} / 18 / 22$ available

at http://www.ohchr.org/Documents/Issues/ClimateChange/A.HRC.RES.18.22.pdf last accessed 13 October 2017.

15 UN Human Rights Security Council, Resolution 26/27, Human Rights and Climate Change, A/HRC/RES/26/27 available at https://documents-ddsny.un.org/doc/UNDOC/GEN/G14/083/51/PDF/G1408351.pdf?OpenElement last accessed 13 October 2017.

16 UN Human Rights Council, Resolution 29/15, Human Rights and Climate Change, $\mathrm{A} / \mathrm{HRC} / \mathrm{RES} / 29 / 15, \quad$ available at https://documents-ddsny.un.org/doc/UNDOC/GEN/G15/163/60/PDF/G1516360.pdf?OpenElement last accessed 13 October 2017.

17 UN Human Rights Council, Resolution 32/33, Human Rights and Climate Change, $\mathrm{A} / \mathrm{HRC} / \mathrm{RES} / 32 / 33$, available at https://daccess-ods.un.org/TMP/7969580.88874817.html last accessed 13 October 2017.

18 United Nations Framework Convention on Climate Change ("Paris Agreement"), UNTS No. 4(2017), signed 22 April 2016, entry into force 4 November 2016. 
common goals are set and intended to be achieved together but leaving States a margin of discretion that fosters commitment proportionally to each nation's real capacity to bind itself to given objectives. The provision of nationally determined contributions (NCDs) is clear evidence for that. What is remarkable is that the Paris Agreement has not overlooked human rights: despite their protection is not provided as binding commitment for States Parties, a generalized and comprehensive human rights-based approach is promoted in the architecture of the Agreement.

Human rights are recalled in the Preamble, which entails strong moral value and persuasion and the reference made impacts the interpretation of the commitments that States have adopted from a broad perspective that goes beyond the Paris Agreement itself. In particular, the relevant statement "[a]cknowledg[es] that climate change is a common concern of humankind [therefore] Parties should, when taking action to address climate change, respect, promote and consider their respective obligations on human rights". It means that compliance with the obligations arising from the Paris Agreement has to result in the adoption of international and domestic policies and measures consistent with the protection of human rights, and capable of suiting the specific needs of the vulnerable groups which are subsequently cited in the text of the provision, as they are particularly exposed to the adverse effects of climate change. Echoing sustainability, the same statement of the Preamble also recalls the right to development and puts in evidence 'intergenerational equity'. ${ }^{19}$ The wording of this clause is not without consequence: it founds a far-sighted approach that requires action that is both prompt and respectful of future generations. Action adopted today cannot prejudice future generations' rights and their conditions of life.

The reference to human rights made in the Paris Agreement, in line with the other previous tools cited above, is particularly significant: it implies that human rights amount to a basic component of States' action that addresses climate change. Including when the protection of the right to health and the right to science are at stake, and issues related to biotechnologies and epigenetics are no exceptions: in this respect, also the reference to the right to development and the call for protection of future generations assume particular relevance because, as clarified more in depth below, they can both benefit or being prejudiced by practical applications of scientific progress. ${ }^{20}$

As stressed above, despite the Paris Agreement does not impose specific human rights duties on States Parties, it recalls their "respective obligations on human rights": by so doing, besides elucidating the content of the morally persuasive exhortation it contains, the Agreement also frames the reference binding framework for each Party. In practice, the reference is to the universal and regional human rights treaties, both

\footnotetext{
19 Paris Agreement, Preamble.

20 See: AKEEM, A., "Genetic Engineering and Sustainable Development: A Philosophical Inquiry", International Conference on Environmental, Biomedical and Biotechnology IPCBEE vol.41 (2012).
} 
generalist and thematic, to which States are bound under international law, and which include the instruments that are relevant for paving the way to the human-rights based approach to biotechnologies and epigenetics as means for fostering human adaptation to climate change theorized here in this study.

\section{THE RESPONSE OF INTERNATIONAL BIOETHICS TO THE NEW HORIZONS OF BIOENGINEERING: STRIKING THE BALANCE BETWEEN ETHICS AND SCIENTIFIC PROGRESS}

The necessary premise for the theorization of human rights States' duties related to bioengineering and epigenetics implies assessment of the solution advanced by Dr. Liao, Dr. Roache and Dr. Sandberg in light of the relevant international instruments. Therefore, the crucial point is assessing whether genome editing entailing human germline alterations is allowed under international law, in particular under the Universal Declaration on Human Genome and Human Rights ${ }^{21}$ and the Convention on Human Rights and Biomedicine, ${ }^{22}$ also known as the Oviedo Convention.

These two instruments marked two important steps for the international community in the field of biolaw twenty years ago. It is not a coincidence that both the Universal Declaration on Human Genome and Human Rights and the Oviedo Convention date back to 1997: the late 1990s and the early 2000s have been a fundamental moment in the history of biolaw and especially of human genome thanks to the Human Genome Project, that produced the first complete sequences of human genomes. ${ }^{23}$ Again, it is not a coincidence that both instruments widely build upon the conception of human dignity, as a founding value and principle that permeates them. Both instruments are the result of a lively ethical debate on the impact of biomedicine on human rights that they take up and boost, and pursue the purpose of fostering harmonization of the different local landscapes in order to promote the development of scientific research and, at the same

21 UN Educational, Scientific and Cultural Organisation (UNESCO), Universal Declaration on the Human Genome and Human Rights, 11 November 1997, available at: http://www.unesco.org/new/en/social-and-human-sciences/themes/bioethics/human-genome-and-humanrights/ last accessed 10 October 2017.

22 The Convention for the Protection of Human Rights and Dignity of the Human Being with regard to the Application of Biology and Medicine: Convention on Human Rights and Biomedicine (ETS No 164) was opened for signature on 4 April 1997 in Oviedo (Spain), entered into force on 1st December 1999, available at http://www.coe.int/en/web/conventions/full-list/-/conventions/treaty/164 last accessed 10 October 2017.

23 For wider information about the Human Genome Project, see: https://www.genome.gov/10001772/all-about-the--human-genome-project-hgp/. For early views and expectations: SPEAKER, S. L., LINDEE, M. S., HANSON, E., A Guide to the Human Genome Project: Technologies, People, and Institutions, Chemical Heritage Foundation, Publication $\mathrm{n}^{\circ} 11$, Philadelphia, 1993. For a more recent comprehensive analysis: PALLADINO, M.A., Understanding the Human Genome Project, Benjamin Cummings, San Francisco, 2006. 
time, ensuring that progress keeps respectful of human dignity and the rights of the subjects involved. Indeed, the Universal Declaration on Human Genome and Human Rights and the Oviedo Convention build upon the acknowledged conception that human rights 'flow' from human dignity, ${ }^{24}$ which provides them their ultimate justification and preserves them from possible abuses and misuses of scientific progress. This is all the more true when latest innovations in bioengineering may apply to human genome, which could lead to unpredictable outcomes and raises serious concerns of unethical practices, that serve human beings to mere scientific interests in breach of beneficence principle and of the primacy of human beings over the interests of science and society. ${ }^{25}$

Before assessing more in-depth the approach adopted by the Universal Declaration on Human Genome and Human Rights and the Oviedo Convention, a distinction has to be made between the two feasible typologies of genome editing, namely interventions concerning human somatic cells alterations, that interest body cells and limit to the adult subject treated, and alterations of the human germline that, otherwise, affect oocyte, sperm and early embryos and are thus transmissible to the progeny. ${ }^{26}$ While interventions on somatic cells are allowed when they pursue therapeutic and not human traits enhancement ends, ${ }^{27}$ human germline alterations are prohibited under international

24 ANDORNO, R., La bioética y la dignidad de la persona, Editorial Tecnos - Grupo Anaya, Madrid, 2012; GROSS ESPIELL, H., "La Dignidad Humana en los Instrumentos Internacionales sobre Derechos Humanos", Anuario de Derechos Humanos. Nueva Época, n 4, 2003, pp. 193-223; NICKEL, J. W., Making sense of human rights: Philosophical reflections on the universal declaration of human rights, University of California Press, Berkeley, 1987. Also see: HAREES, L., The Mirage of Dignity on the highways of Human 'Progress': the bystanders' persepctive, Authorhouse, Bloomington, 2012.

25 MUYARADZI, M., "Critical reflections on the principle of beneficence in biomedicine", Pan African Medical Journal $\mathrm{n}^{\circ} \quad 11(29), \quad 2012, \quad$ available https://www.ncbi.nlm.nih.gov/pmc/articles/PMC3325067/pdf/PAMJ-11-29.pdf last accessed 7 October 2017.

26 ORMOND, K.E., MORTLOCK, D.P., SCHOLES, D.T., BOMBARD, Y., BRODY, L.C., FAUCETT, A., GARRISON, N.A., HERCHER, L., ISASI, R., MIDDLETON, A., MUSUNURU, K., SHRINER, D., VIRANI, A., YOUNG, C.E., "Human Germline Genome Editing", The American Journal of Human Genetics, $\mathrm{n}^{\circ} 101$ (2), 3 August 2017, pp. 167-176. Also see: HANSELL, G.L., H+/-: Transhumanism and Its Critics, Metanexus, Philadelphia, 2011.

27 In this regard see Article 5 of the Universal Declaration on the Human Genome and Human Rights and Article 13 of the Convention on Human Rights and Biomedicine. See GUNDERSON, M., "Enhancing Human Rights: How the Use of Human Rights Treaties to Prohibit Genetic Engineering Weakens Human Rights", Journal of Evolution and Technology, $\mathrm{n}^{\circ}$ 18(1), May 2008, pp. 27-34, and SMITH, K.R., "Gene Therapy: The Potential Applicability of Gene Transfer Technology to the Human Germline", International Journal of Medical Science, $\mathrm{n}^{\circ}$ 1(2), 2004, pp. 76-91. See: ANDORNO, R., "Can human germline alterations be ethically justified?", Bioética Forum, n 10 (2), 2017, Editorial; MAZZONI, M., RODOTà, S., ZATTI, P., Trattato Di Biodiritto. Il governo del Corpo, GIUFFRé, Milano, 2011. McLEAN, S.A.M., Genetics and Gene Therapy, Routledge, London, 2017. 
law and by a wide number of national regulations, ${ }^{28}$ due to the serious concerns related to the transmissibility of such modifications to future generations.

The Universal Declaration on the Human Genome and Human Rights expressly qualifies human germline alterations as contrary to human dignity, at Article $24 .{ }^{29}$ This statement represents a specification of the constant reference to human dignity as the founding value aimed at underlying and guiding research in its developments, since human genome, in a symbolic sense, can be intended as heritage of mankind. This perspective is shared and restated also by the Oviedo Convention, whose Article 13 provides that "[a]n intervention seeking to modify the human genome may only be undertaken for preventive, diagnostic or therapeutic purposes and only if its aim is not to introduce any modification in the genome of any descendants", which appears as a specification of the statement contained in the Explanatory Report to the Oviedo Convention where, with reference to the Preamble, it is clarified that "the developments in medicine and biology [...] should be used only for the benefit of present and future generations and not be diverted in ways that run counter to their proper objective". Scientific progress, indeed, cannot be diverted in order to suit unorthodox purposes, but has to serve always the "benefits of progress to the whole of mankind", a goal to pursue through international cooperation as the Explanatory Report clarifies, in line with the globalization of the challenges scientific evolution poses, especially in the bioethical field. The serious concerns of eugenic threats accounts for the perspective enshrined in the Oviedo Convention, as well as in the Universal Declaration on Human Genome and Human Rights, and explains the call for international debate and concerted action, as the only adequate context where to additionally ensure solidarity towards less developed and more vulnerable countries, that could be easier targets of unethical intents of experimentation.

An observation can be made quite promptly when the approach to human germline alterations adopted by the Universal Declaration on Human Genome and Human Rights and the Oviedo Convention is considered: in this case, law has anticipated scientific progress, which is definitely unusual in the field of biolaw, where it is common that law lags behind science. ${ }^{30}$ In fact, scientific progress had not made remarkable steps ahead in

28 With regard to some domestic experiences, see: ANDORNO, R., "Biomedicine and international human rights law: in search of a global consensus", Bulletin of the World Health Organization, ${ }^{\circ}$ 80, 2002, pp. 959-963, recalling, for example, Brazil Law 8974/95. For wider analysis, see: ANDORNO, R., "Global bioethics at UNESCO: in defence of the Universal Declaration on Bioethics and Human Rights", Journal of Medical Ethics, $\mathrm{n}^{\circ} 33$ (3), 2007, pp. 150-154.

29 In particular, Article 24 of the UNESCO Universal Declaration on the Human Genome and Human Rights defines germline interventions as "contrary to human dignity".

30 GARCIA SAN JOSÉ, D.I., International Bio Law - An International Overview of Developments in Human Embryo Research and Experimentation, Ediciones Laborum, Murcia, 2010. Also see: CARDOSO RODRIGUES, R.A., 'Dos Novos Desafios À Ética, À Bioética e ao Biodireito na (Nova) Era 
relation to human germline alterations until the advent of the CRISPR/Cas9, a genome editing technique that enables scientists to eliminate and replace entire sections of DNA, with more precision and at more affordable costs than in the past. The CRISPR/Cas9 technique could be used on human embryos, which makes human germline alterations a possibility in scientific research which, nonetheless, would be at odds with the Universal Declaration on Human Genome and Human Rights and the Oviedo Convention. ${ }^{31}$ What is more, a shift of perspective is unlikely. In October 2015, a UNESCO Panel of Experts launched a call for a temporary ban on human germline editing, which was followed by an appeal issued by some scientists for a general ban on human germline alterations through use of the CRISPR/Cas9 technique and similar techniques. A couple of months later, in December 2015 the Council of Europe's Committee on Bioethics adopted a Statement on Genome Editing Technologies ${ }^{32}$ stressing the importance of the role of the Oviedo Convention for dealing with human germline interventions. In the same period, the Organizing Committee for the International Summit on Human Gene Editing, in which outstanding researchers in the field participated, published a summit statement where it did not exclude running in-vitro human germline genetic interventions. Some other scientists joined the debate arguing that in-vitro research implying human germline editing may be a feasible route. Nonetheless, these voices are still a minority in the international scientific and non-scientific community, which means that consensus on prohibition on human germline alterations is still unchanged. It is interesting to stress that prohibition on human germline interventions, along with the rejection of human cloning for reproductive purposes, represents an exceptional case where the international community has expressed a converging view in the field of biolaw, where usually a variety of perspectives are called to confront. ${ }^{33}$

da (R)Evolução Biotecnológica:Vias e Reflexões", Revista Bioderecho.es, $\mathrm{n}^{\circ}$ 3, 2016, available at http://revistas.um.es/bioderecho/article/view/260451/197001 last accessed 13 October 2017.

31 LOCKYER, E.L., "The potential of CRISPR-Cas9 for treating genetic disorders", Bioscience Horizons, $\quad \mathrm{n}^{\circ} \quad 9, \quad 2016, \quad$ available at https://academic.oup.com/biohorizons/article/doi/10.1093/biohorizons/hzw012/2562795 last accessed 7 October 2017; SMITH, K.R., "Gene Therapy: The Potential Applicability of Gene Transfer Technology to the Human Germline", cited above n. 27. For deeper analysis, also see: ESER, A., "Perspectives of medical law under the auspices of modern biotechnology"; Revista de Derecho y Genona Humano, Numero Extraordinario, 2014, pp. 87-101.

32 Council of Europe, Committe on Bioethics, "Statement on genome editing technologies", 8th Meeting, 1-4 December 2015, available at https://rm.coe.int/168049034a last accessed 14 October 2017Further information available at https://www.coe.int/en/web/bioethics/-/gene-editing?desktop=true last accessed 14 October 2017.

33 For deeper analyis see ANDORNO, R., "Biomedicine and international human rights law: in search of a global consensus", cited above n. 28. Also see: ANDORNO, R., Principles of international biolaw. Seeking common ground at the intersection of bioethics and human rights, Bruylant, Bruxelles, 2013; HILDT, E., "Human Germline Interventions-Think First", Frontiers in Genetics, nº 7, Article n 81, 2016. 
That being said, it appears quite clear that the thesis advanced by Dr. Liao, Dr. Roache and Dr. Sandberg would clash with the principles set out by international law in the field of human germline interventions transmissible to future generations. Nor reference to the less strict conception of the right to 'genetic identity', ${ }^{34}$ which allows human germline modifications for the prevention of genetic disease, would lead to different conclusions. This entitlement builds upon the conception of human dignity, and protects future generations from alterations of their genetic structure caused by the intervention of precedent generations. The rationale underlying the protection of genetic identity lies basically in two justifications: firstly, as some authoritative scholarship has stressed, present generation do not have the right to genetically predetermine the features of future generation according to their contingent conception of is "good" or "bad". Moreover, some objections concern future generations' self-perception as "autonomous beings" and not mere objects or artefacts. A similar reasoning, along with the protection of parenthood, accounts for the prohibition of reproductive cloning as well. ${ }^{35}$ Again, a major threat is the spectre of eugenics and the fear for the creation of an elite of genetically improved subjects, capable of prevaricating non-genetically modified humans. Concerns are so serious that some scholars have suggested the adoption of an international "Convention on the Preservation of the Human Species", ${ }^{36}$ for the purpose of preserving the basic features of human nature which also underlie the human rights system. At the regional level, genetic identity finds protection in the Charter of Fundamental Rights of the European Union, ${ }^{37}$ which sets "the prohibition of eugenic practices, in particular those

$34 \quad$ See GUNDERSON, M., "Enhancing Human Rights: How the Use of Human Rights Treaties to Prohibit Genetic Engineering Weakens Human Rights", cited above n. 27. ASHCROFT, R., "Genetic information and genetic identity", in THOMPSON, A. K., CHADWICK, R.F. (eds.), Genetic Information, Kluwer Academic, Plenum Publishing, New York, 1999. Also see: KLITZMAN, R., ““'Am I my genes?”: Questions of identity among individuals confronting genetic disease", Genetics in Medicine, $\mathrm{n}^{\circ} 11(12)$, December 2009, pp. 880-889.

35 ANDORNO, R., "Biomedicine and international human rights law: in search of a global consensus", cited above n. 28. HIPP, J., ATALA, A., "Tissue engineering, stem cells, cloning, and parthenogenesis: new paradigms for therapy", Journal of Experimental and Clinical Assisted Reproduction, $\mathrm{n}^{\circ}$ 1(3), 2004, available at https://www.ncbi.nlm.nih.gov/pmc/articles/PMC539246/pdf/1743-1050-1-3.pdf last accessed 14 October 2017. ANNAS, G., ANDREWS, L., ISASI, R., "Protecting the endangered human: toward an international treaty prohibiting cloning and inheritable alterations", American Journal of Law and Medicine, $\mathrm{n}^{\circ} 28$ (2-3), 2002, pp. 151-178.

36 See GUNDERSON, M., "Enhancing Human Rights: How the Use of Human Rights Treaties to Prohibit Genetic Engineering Weakens Human Rights", cited above n. 27. ANNAS, G., ANDREWS, L., ISASI, R., "Protecting the endangered human: toward an international treaty prohibiting cloning and inheritable alterations", cited above n. 35 .

37 European Union, Charter of Fundamental Rights of the European Union, 26 October 2012, 2012/C 326/02, available at http://eur-lex.europa.eu/legal-content/EN/TXT/?uri=CELEX:12012P/TXT last accessed 14 October 2017. For closer analysis of the EU Charter, it is interesting to visit the website http://fra.europa.eu/en/charterpedia. For the European Union's more specific views on gene editing, see the "Statement on Gene Editing", European Group on Ethics in Science and New Technologies, https://ec.europa.eu/research/ege/pdf/gene editing_ege statement.pdf last accessed 13 October 2017. For deeper analysis: DE SADELEER, N., "Enforcing EUCHR Principles and Fundamental Rights in 
aiming at the selection of persons" where it protects physical integrity while instrumentally safeguarding human dignity. In this regard, it is particularly significant here to stress that this provision finds correspondence and practical enforcement in EU's "Biotechnology Directive", where it "exclude[s] unequivocally from patentability processes for modifying the germ line genetic identity of human beings", as practices contrary to ordre public according to widespread Member States' consensus. ${ }^{38}$ That being said, it is evident the human germline alterations affecting the body-size would not serve any preventive purpose, otherwise would address a trait that impacts on the core of genetic identity. ${ }^{39}$

Once feasibility of genome editing is framed under international law and once the viability human germline cells alterations is ruled out, human somatic cells alterations for therapeutic purposes remains as a possible route to foster human adaptation to the challenges posed by climate change. In fact, human somatic cells alterations aimed at enhancing human traits, are excluded for analogous reasons, since the relevant international instruments only allow therapeutic interventions, including when they are preventive, and risks of eugenics and discrimination are similar. Indirect rejection of genome editing for purposes of enhancement can be found in above-mentioned Article 13 of the Oviedo Convention and in Article 12(b) of the Universal Declaration on Human Genome and Human Rights, which expressly clarifies that the application of research "shall seek to offer relief from suffering and improve the health of individuals and humankind as a whole". Furthermore, this study argues that epigenetics represents a

Environmental Cases", Nordic Journal of International Law, n 81, 2012, 39-74, and KIM, J., "Regulating Economic Development: Environmental and Social Standards of the AIIB and the IFC", Harvard Journal of International Law, 21 April 2016. available at http://www.harvardilj.org/2016/04/regulating-economicdevelopment-environmental-and-social-standards-of-the-aiib-and-the-ifc/ last accessed 12 October 2017.

$38 \quad$ Directive 98/44/EC of the European Parliament and of the Council of 6 July 1998 on the legal protection of biotechnological inventions, Recital 40. Also see Recitals 16 and 38, and Article 6(2)(b). See: NUEVO LÓPEZ, P., "Dignidad humana y patentabilidad de invenciones biomédicas”, Estudios de Deusto, $\mathrm{n}^{\circ} 60$ (1) (2012), pp. 327-355. See: GARCIA SAN JOSÉ, D., "Derecho de la Unión, Investigación Embrionaria Humana y Patentes Biológicas", Revista de Derecho Comunitario Europeo, n 41, EneroAbril 2012, pp. 161-180; SHEARD, A., "Patenting Stem Cell Technologies in Europe", Cold Spring Harbour Perspective in Medicine, $\mathrm{n}^{\circ}$ 5(3), March 2015, available at $<$ https://www.ncbi.nlm.nih.gov/pmc/articles/PMC4355253/> last accessed 20 October 2017. For wider analysis, see: DE MIGUEL BERIAIN, Í., JORQUI AZOFRA, M., "Patentes y biotecnología: ¿un dilema insuperable?", Anuario de filosofia del derecho, n 19, 2002, pp. 283-307.

39 See GUNDERSON, M., "Enhancing Human Rights: How the Use of Human Rights Treaties to Prohibit Genetic Engineering Weakens Human Rights", cited above n. 27. ASHCROFT, R., "Genetic information and genetic identity", cited above n. 34. Also see KLITZMAN, R., ““Am I my genes?": Questions of identity among individuals confronting genetic disease", cited above n. 34 . For an in depthanalysis, see: ANNAS, G., ANDREWS, L., ISASI, R., "Protecting the endangered human: toward an international treaty prohibiting cloning and inheritable alterations", cited above n. 35 . 
valuable way as well and that both solutions may find a justification in international human rights law, as closer analysis below aims at demonstrating.

\section{HUMAN RIGHTS: AN APPROPRIATE PARADIGM FOR GENOME EDITING AND EPIGENETICS AS SOLUTIONS TO COPE WITH CLIMATE CHANGE-RELATED CHALLENGES?}

Human rights treaties have been used as suitable legal instruments to address climate change on several occasions: even if these tools are not expressly dedicated to environmental issues and sometimes they were adopted decades ago, in a different historical context, their nature of living instruments has enabled them to welcome environmental claims when connected to the entitlements they enshrine. Several examples can be found in the jurisprudence of some regional bodies. The European Court of Human Rights (ECtHR), ${ }^{40}$ for example, has addressed the impact of the adverse effects of climate change on the right to life, the right to private and family life and the right to property; the Inter-American Commission on Human Rights (IACHR) ${ }^{41}$ has granted protection to climate change-related instances concerning the preservation of the cultural identity, the traditions and the land of indigenous communities.

There are several reasons why international human rights law has become a suitable response to climate change. Firstly, because the adverse effects of climate change

40 See, for example: Budayeva and Others v. Russia, Application nos. 15339/02, 21166/02, 20058/02, 11673/02 and 15343/02, European Court of Human Rights (Court, First Section), Judgment (Merits and Just Satisfaction), 20 March 2008, Case Reports, available at https://hudoc.echr.coe.int/eng\#\{"fulltext":["budayeva"],"documentcollectionid2":["GRANDCHAMBER" "CHAMBER"],"itemid":["001-85436"]\} last accessed 12 October 2017; Kolyadenko and Others v. Russia, Applications nos. 17423/05, 20534/05, 20678/05, 23263/05, 24283/05 and 35673/05, European Court of Human Rights (Court, First Section), Judgment (Merit and Just Satisfaction), 28 February 2012, available at

https://hudoc.echr.coe.int/eng\#\{"fulltext":["Kolyadenko"],"documentcollectionid2":["GRANDCHAMBE R","CHAMBER"],"itemid":["001-109283"]\} last accessed 12 October 2017; Hadzhiyska v. Bulgaria, Application no. 20701/09, Decision, Court (Fourth Section), 15 May 2012, available at https://hudoc.echr.coe.int/eng\#\{"fulltext":["hadzhiyska"],"itemid":["001-111208"]\} last accessed 12 October 2017.

$41 \quad$ Inuit Circumpolar Conference, Petition to the Inter-American Commission on Human Rights Seeking Relief from Violations Resulting from Global Warming caused by Acts and Omissions of the United States (7 December 2005), available http://www.inuitcircumpolar.com/uploads/3/0/5/4/30542564/finalpetitioni cc.pdf last accessed 12 October 2017; Arctic Athabaskan Council, Petition to the Inter-American Commission on Human Rights Seeking Relief from Violations of the Rights of Arctic Athabaskan Peoples Resulting from Rapid Arctic Warming and Melting caused by Emissions of Black Carbon by Canada (23 April 2013), available at http://earthjustice.org/sites/default/files/AAC PETITION 13-04-23a.pdf. DE LA ROSA JAIMES, V., "Climate Change and Human Rights Litigation in Europe and the Americas", Seattle Journal of Environmental Law, $\mathrm{n}^{\circ} 5$ (1), 2015, pp. 164-198. 
are capable of affecting the lives of individuals within States' borders, prejudicing the enjoyment of their rights; secondly, for the climatic implications on global public health, for example in relation to the dispersion of toxicants and the risks of epidemics or even pandemics. Last but not least, from a regulatory viewpoint, because climate change requires concerted action through international cooperation, and human rights offer a 'lowest common denominator', which helps to identify important shared standards of protection, both universally and regionally.

That being said, the point here is assessing whether and how international human rights law can provide accommodation for human beings' adaptation to climate change through biolegal solutions, namely therapeutic human somatic cells alterations and epigenetics.

Therapeutic interventions on human somatic cells were already put in practice with good results in the 1990s and early 2000s, to treat severe combined immunodeficiency (SCID). However, on other occasions in the same period the results were not as encouraging and even turned out to be lethal for the patient in the case of Jesse Gelsinger, who suffered from ornithine transcarbamylase (OTC) deficiency. ${ }^{42}$ Epigenetics, that literally means "on tops" or "above" the genetics, ${ }^{43}$ does not determine any alteration in the genotype of the subject interested, but merely affects the phenotype, since it alters gene activity but leaves gene sequence unchanged. Among the main examples of epigenetic interventions currently feasible, DNA methylation and chromatin modification can be cited. ${ }^{44}$ There is scientific evidence that epigenetic interventions carried out on adult subjects are also transmissible to the progeny in a multigenerational and intergenerational fashion. ${ }^{45}$ However, epigenetic alterations in genes' activity are

42 FEITO GRANDE, L., "Ingeniería genética (Ético)", ENCICLOPEDIA de BIODERECHO y BIOÉTICA, available at http://enciclopedia-bioderecho.com/voces/185 last accessed 15 October 2017; MARIS MARTÍNEZ, S., "Ingeniería genética (Jurídico)", ENCICLOPEDIA de BIODERECHO y BIOÉTICA, available at http://enciclopedia-bioderecho.com/voces/186 last accessed 15 October 2017. FRETWELL WILSON, R., "The Death of Jesse Gelsinger: New Evidence of the Influence of Money and Prestige in Human Research", American Journal of Law \& Medicine, n 36, 2010, pp. 295-325; also see: OBASOGIE, O. K., “Ten Years Later: Jesse Gelsinger's Death and Human Subjects Protection”, The Hastings Center, availbale at http://www.thehastingscenter.org/ten-years-later-jesse-gelsingers-death-andhuman-subjects-protection/ last accessed 15 October 2017.

43 See National U.S. National Library of Medicine, "What is epigenetics", available at https://ghr.nlm.nih.gov/primer/howgeneswork/epigenome last accessed 12 November 2017.

44 VOGT, G., "Facilitation of environmental adaptation and evolution by epigenetic phenotype variation: insights from clonal, invasive, polyploid, and domesticated animals", Environmental Epigenetics, $\mathrm{n}^{\circ}$ 3(1), 2017, pp. 1-17; WEINHOLD, B., "Epigenetics: the science of change", Environmental Health Perspectives, $\mathrm{n}^{\circ}$ 114(3), March 2006, A160-A167.

45 JI, H., KHURANA HERSHEY G.K., "Genetic and epigenetic influence on the response to environmental particulate matter", Journal of Allergy and Clinical Immunology, n 129(1), January 2012, PP. 33-41. SKINNER, M.K., "Epigenetic Transgenerational Phenotype? F3 or F2", Reproductive Toxicology, $\mathrm{n}^{\circ}$ 25(1), 2008, pp. 2-6. 
reversible, differently from human germline cells editing. ${ }^{46}$ Epigenetics may represent a helpful solution for tackling the adverse effects of climate change on individuals in two ways: as a means for prevention of the onset of genetic diseases, by 'inhibiting' or in some ways intervening on gene's activity; again, as a means for elaborating therapeutic solutions to reverse an adverse epigenetic process once environmental conditions have triggered it. As to the first path advanced, innovative epigenetic-based diagnostic, preventive and therapeutic strategies may be suggested for coping with human diseases. ${ }^{47}$ As to the second application advanced, reversibility of alterations in the epigenome may be promoted through dietary responses, as the assumption of dietary phytochemicals and supplements, which could be very easily incorporated in daily life. In practice, interesting results were achieved through administration of epi-drugs, namely drugs that have been devised for inhibiting epigenetic enzymes, as it was the case for breast cancer. ${ }^{48}$ Human epigenetic alterations are variously triggered by adverse environmental conditions related to climate change in our modern globalized and increasingly industrialized world, as dispersion of toxicants due to growing transport of pollution and legacy contaminants and changes in agricultural practices. ${ }^{49}$ In literature, for example, inorganic arsenic was linked to DNA methylation. Exposure to environmental toxicants has a deleterious impact on human beings and there is growing evidence that links it to the onset of wide array of non-infectious diseases, as polycystic ovary syndrome (PCOS), germ cell apoptosis, increased risk of developing autism-spectrum disorders and pregnancy defects. Prenatal exposure to such environmental conditions is capable of dysregulating the fetal epigenome, which may lead up to the onset of diseases during early stages of life and to developmental disorders. ${ }^{50}$ What is more, these conditions are capable of affecting in the long-term the epigenome of gametes, and thus would be passed on to the progeny. Early

46 TOMPKINS, J.D., HALlC, C., CHENC V.C.-Y., XUEJUN LIE, A., WUE, X., HSUC, D., COUTUREC, L.A., RIGGSA, A.D., "Epigenetic stability, adaptability, and reversibility in human embryonic stem cells", PNAS, n 109 (31), 31 July 2012, available at http://www.pnas.org/content/109/31/12544.full.pdf last accessed 15 October 2017.

$47 \quad$ HAIJKOVA P., "Epigenetic reprogramming of the germline: towards the ground state of the epigenome", Philosophical Transaction of the Royal Society, n' 366, 2011, pp. 2266-2273.

48 SHUKLA, S., MEERAN, S.M., KATIYAR, S.K., "Epigenetic regulation by selected dietary phytochemicals in cancer chemoprevention”, Cancer Letters, n' 355(1), 1 December 2014, pp. 9-17.

49 VALLERO, D.A., Environmental Biotechnology: A Biosystems Approach (Elsevier, 2nd Ed., 2016).

$50 \quad$ KEIL K.P., LEIN, P.J., "DNA methylation: a mechanism linking environmental chemical exposures to risk of autism spectrum disorders", Environmental Epigenetics, $\mathrm{n}^{\circ} 1$, 2015, available at https://academic.oup.com/eep/article/2/1/dvv012/2464729 last accessed 13 October 2017. See: GARCÍA SAN JOSÉ, D., "Epigenética y gestación por sustitución: más razones a favor de una regulación internacional para un negocio global", Anuario Mexicano de Derecho Internacional, vol. XVII, 2017, pp. 329-368. 
evidence was provided by animal experimentations, but data are increasingly finding confirmation with regard to humans. ${ }^{51}$

Epigenetics, thus, may help coping with a quite wide array of invalidating diseases and, even if there is evidence of transmissibility to the progeny of the results of its applications, they are likely to reconcile with the prohibition of human germline alterations for two reasons: firstly, because, as anticipated above, they would affect only the phenotype and not the genotype, and then they trigger a reversible process in genes' activity. Secondly, epigenetic interventions would not clash with the less rigorous conception of the right to genetic identity strict conception, as they would serve a therapeutic purpose.

Primary guidance for assessing whether and how interventions on human somatic cells and the use of epigenetics are viable solution to address adaptation to climate change under international human rights law is offered by the conception of human dignity and, from some viewpoints, by the notion of "dignified existence". Human dignity is a founding value in the field of human rights and, in particular, in the field of biolaw, where it plays a 'unifying' role that transcends and overcomes ethical relativism (ANDORNO, 2002, 961). ${ }^{52}$ Despite some scholars have claimed that it is a mere rhetorical conception, void of meaning, human dignity has globally affirmed as an absolute and unconditional value, all the more in the field of biolaw, where it has often provided the main parameter for assessing the admissibility of given scientific practices. Under international human rights law, human dignity may be intended in a twofold sense that echoes the Kantian conception, as "empowerment" and as "constraint". ${ }^{53}$ In the latter case, human dignity is intended as a "constraint on autonomy", which is pre-eminently focused on duties in the interest of common good and which implies that biomedical practice should be led by a common vision of human dignity that transcends the individual sphere. Otherwise, human dignity as "empowerment" is focused on a human rights perspective, and requires the

51 DOLINOY, D.C., JIRTLE, R., "Environmental epigenomics in human health and disease", Environmental and Molecular Mutagenesis, $\mathrm{n}^{\circ}$ 49(1), January 2008, pp. 4-8; GUERRERO-BOSAGNA C., JENSEN, P., "Globalization, climate change, and transgenerational epigenetic inheritance: will our descendants be at risk?", Clinical Epigenetics ${ }^{\circ} 7(1), 2015$, pp. 8-13.

$52 \quad$ ANDORNO, R., "Biomedicine and international human rights law", cited above n. 28. BINDER, G., "Cultural Relativism and Cultural Imperialism in Human Rights Law", Buffalo Human Rights Law Review, n 5, 1999, pp. 211-221; SPAAK, T., "Moral Relativism and Human Rights", Buffalo Human Rights Law Review, Vol. 13, 2007, available at https://papers.ssrn.com/sol3/papers.cfm?abstract id=923445 last accessed 7 October 2017. From a wider perspective, for deepening the analysis: MORELLI, M., "El concepto del bioderecho y los derechos humanos", Vida y Ética, n 1, año 11, 2010, pp. 194-222. Also see: HERRERA FLORES, J., Los derechos humanos como productos culturales: Crítica del humanismo abstracto, Catarata, Madrid, 2005; NICKEL, J., REIDY, K., Relativism, Self-Determination, and Human Rights, available at http://web.utk.edu/ dreidy/nickelreidyfinaldraft2005.pdf last accessed 11 October 2017.

53 ANDORNO, R., "Dignidad Humana", Enciclopedia de Bioderecho y Bioética, available at http://enciclopedia-bioderecho.com/voces/120 last accessed 15 October 2017. 
fulfilment of the conditions necessary for the full development of human personality. International human rights bodies have relied on both conceptions of human dignity and, for our purposes, reference to their jurisprudence built upon the perspective of "empowerment" for the enjoyment of human rights is particularly significant for clarifying the suitable human-rights approach to consider. ${ }^{54}$

In this respect, it is interesting to recall the conception of vida digna, that is 'dignified existence', elaborated by the Inter-American Court of Human Rights (IACtHR), which represents a basic feature of the Court's approach to further elaboration of the standards of protection of the entitlements enshrined in the American Convention on Human Rights (ACHR). A dignified existence is intended as the unavoidable precondition for personal development, which allows the enjoyment of human rights, and applies transcendentally in the system of the Convention, as it was the case for Artavia Murillo $v$ Costa Rica ruling, ${ }^{55}$ the only decision adopted by the IACtHR in the field of biolaw. In that judgment, the Court held that the prohibition of in-vitro fertilization set by Costa Rica breached the right to privacy, the right to personal liberty, the right to physical, mental and moral integrity and the right to found a family protected under the ACHR. What is particularly significant here is that the Court recognized the right to access to given biomedical techniques, namely in-vitro fertilization, under the ACHR, by establishing that the rights to private life and to personal integrity are also directly and immediately linked to health care. From a wider viewpoint, in connection to human dignity and the conception of dignified life, the Court has affirmed the right to access to the highest attainable standards of health, including health care and assistance, treatment and medication, without any discrimination. ${ }^{56}$ In Strasbourg, the European Court of

$54 \quad$ Ibid. For a deeper view on life, law and dignity see RODOTA', S., La Vita e le Regole. Tra Diritto e Non Diritto, laFeltrinelli, Milano, 2006.

55 IACtHR, Case of Artavia Murillo et al. (in vitro fertilization) v. Costa Rica. Preliminary Objections, Merits, Reparations and Costs. Judgment of 28 November 2012, Series C No. 257, para. 148, available at http://www.corteidh.or.cr/docs/casos/articulos/seriec 257 esp.pdf last accesssed 14 October 2017, which also incorporated the notion of health enshrined in the Preamble to the Constitution of the World Health Organization as adopted by the International Health Conference, New York, 19-22 June 1946, Official Records of the World Health Organization, no. 2, p. 100. PASQUALUCCI, J., "The Right to a Dignified Life (Vida Digna): The Integration of Social and Economic Rights with Civil and Political Rights in the Inter-American Human Rights System", Hastings International and Comparative Law Review, $\mathrm{n}^{\circ} 31(1), 2008$, pp. 1-32.

$56 \quad$ See, among the numerous rulings: Case of the Yakye Axa Indigenous Community v. Paraguay, Merits, Reparations and Costs. Judgment of 1 June 2005. Series C No. 125, paras. 166, 167. On this occasion, the IACtHR defined the scope of the right to health by incorporating the "highest attainable standards of health" contemplated by the UN CESCR General Comment n.14, and provided an interpretation of the right to health, in close connection with the right to food and access to clean water, as a means for preserving indigenous communities' cultural identity and deep relationship with their ancestral lands, in the framework of vida digna. IACtHR, Case of Ximenes-Lopes v. Brazil. Merits, Reparations and Costs. Judgment of 4 July 2006. Series C No. 149, para. 99; IACtHR, Case of Albán Cornejo et al. v Ecuador. Merits, Reparations, and Costs. Judgment of 22 November 2007, Series C No. 171, para. 121; 
Human Rights (ECtHR), that has developed a wide and settled jurisprudence in the field of biolaw, has relied on human dignity to ensure access to adequate health care, especially to persons under detention or imprisonment, under Article 3 of the European Convention on Human Rights (ECHR), which enshrines the prohibition of torture and inhuman and degrading treatment, and almost recognized the right to ensure continuing access to palliative care under the Convention in the case D. $v$ the United Kingdom. ${ }^{57}$ The case Aleksanyan $v$ Russia ${ }^{58}$ provides an example of the approach under consideration, especially where the Court relied on human dignity for finding that Russia had "failed to take sufficient care of the applicant's health to ensure that he did not suffer treatment contrary to Article 3 of the Convention". ${ }^{59}$ In particular, the denial of access to appropriate health assistance and treatment constituted inhuman and degrading treatment, since it "undermined [the applicant's] dignity and entailed particularly acute hardship, causing suffering beyond that inevitably associated with a prison sentence and the illnesses he suffered from". ${ }^{60}$ This view is not exceptional in the Strasbourg jurisprudence, otherwise it is widely restated in the Court's decisions, where denial of access to appropriate medical assistance and treatment amounts to a breach of the Convention. Moreover, although reference to human dignity is not generalized in this context, the ECtHR has recognized the right to timely access to amniocentesis and the right to access to abortion services under Article 8 of the Convention, occasionally in conjunction with Article 3 of the ECHR. ${ }^{61}$ At the global level, "[e]very human being is entitled to the enjoyment of the highest attainable standard of health conducive to living a life in dignity" under Article 12 of the International Covenant on Economic, Social and Cultural Rights (ICESCR), ${ }^{62}$ since "[h] ealth is a fundamental human right indispensable for the exercise of other human rights", as the Committee on Economic, Social and Cultural Rights has clarified in General Comment No. 14 on "The Right to the Highest Attainable Standard of Health". ${ }^{63}$ It is interesting here to stress that the wording of Article 12 of the ICESCR,

IACtHR Case of Ver-Vera et al. v. Ecuador, Preliminary Objection, Merits, Reparations and Costs. Judgement of 19 May 2011. Series C No. 226, para. 43.

57 D. v. the United Kingdom (1997) 24 EHRR 423, avialable at http://www.refworld.org/cases,ECHR,46deb3452.html last accessed 14 October 2017.

$58 \quad$ Aleksanyan v. Russia, Application no. 46468/06, European Court of Human Rights (Court, First

Section), Judgment (Merits and Just Satisfaction), 22 December 2008, available at https://hudoc.echr.coe.int/eng\#\{"itemid":["001-90390"]\} last accessed 14 October 2017.

$59 \quad$ Ibid., para. 158.

$60 \quad$ Ibid.

61 R.R. v. Poland, Application no. 27617/04, European Court of Human Rights (Court, Fourth Section), Judgment (Mertis and Just Satisfaction), 26 May 2011, Reports of Judgments and Decisions 2011 (extracts), available at https://hudoc.echr.coe.int/eng\#\{"itemid":["001-104911"]\} last accessed 15 October 2017.

62 UN General Assembly, International Covenant on Economic, Social and Cultural Rights, 16 December 1966, United Nations, Treaty Series, vol. 993, p. 3, available at http://www.ohchr.org/EN/ProfessionalInterest/Pages/CESCR.aspx last accessed 15 October 2017.

63 See General Comment No. 14 (2000) on the Right to the Highest Attainable Standard of Health, available at http://www.refworld.org/pdfid/4538838d0.pdf last accessed 15 October 2017. 
where it ensures the "highest attainable standards of physical and mental health", echoes the language of the Constitution of the World Health Organization (WHO) that defines "the highest attainable standard of health as a fundamental right of every human being". In practice, appropriate enforcement is fostered by the paradigm of the "4-A scheme", which helps to elucidate State obligations about the conditions for best enjoyment of the right. The "4-A scheme" hinges on availability, accessibility, acceptability and adaptability which turns into quality when health is at stake, and substantially entails that health services, goods and facilities, be made available in sufficient quantity ad be accessible without discrimination, physically, economically and informationally. Acceptability implies that health services, goods and facilities offered are consistent with medical ethics, and their good scientific and medical quality has to ensured. ${ }^{64}$

What can be inferred here is, firstly, that use of therapeutic human somatic cells interventions and of epigenetic-based diagnostic, preventive and therapeutic strategies is consistent with an empowering conception of human dignity, since they enable human beings to enjoy a dignified existence and the full personal development by improving their adaptation to adverse climate-change related environmental conditions capable of prejudicing their health and well-being. Secondly, what emerges is that access to therapeutic human somatic cells interventions and epigenetic-based diagnostic, preventive and therapeutic strategies can be claimed as an entitlement under international human rights law. This appears all the more arguable in light of the human rights framework of the European Union. The Charter of Fundamental Rights of the European Union and the "Biotechnology Directive" could be recalled in order to provide confirmation of the acceptability of therapeutic human somatic cells alterations and epigenetic-based diagnostic, preventive and therapeutic strategies. This may be argued especially when we consider that the Explanations concerning Article 3 of the Charter, which offer guidance on the scope of application of the provision, relate "eugenic practices" and the selection of persons to the reproductive sphere. In this regard, it may be advanced that the protection of physical integrity instrumentally to and in conjunction with human dignity allows practices intended to ensure "access" to medical processes

64 DONDERS, Y., "The right to enjoy the benefits of scientific progress: in search of state obligations in relation to health", Medicine, Health Care, and Philosophy, $n^{\circ}$ 14(4), November 2011, pp. 371-381. The Committee on Economic, Social and Cultural Rights has recalled and elucidated the concept of 'core obligations' in the following General Comments: General Comment no. 3 (1990) on the Nature of State Parties Obligations, para. 10; General Comment No. 12 (1999) on The Right to Adequate Food, para. 8; General Comment No. 13 (1999) on the Right to Education, para. 57; General Comment No. 14 (2000) on the Right to the Highest Attainable Standard of Health, para. 43-45. In this regard, guidance is offered also by Primary health care: report of the International Conference on Primary Health Care, Alma-Ata, USSR, 6-12 September 1978, jointly sponsored by the World Health Organization and the United Nations Children's Fund and by the UN COMMITTEE ON ECONOMIC, SOCIAL AND CULTURAL RIGHTS, GUIDELINES ON REPORTING QUESTIONS RELATING TO ARTICLE 12 OF THE CESCR, UN Doc. E/1991/23, pp. 88-110, which also provides some indicators or benchmarks for assessing States' commitment to ensure the minimum level of health through their policy and resources management. 
aimed to enhance a dignified existence, keeping in mind that the conception of human dignity enshrined in the Charter, as authoritatively clarified in scholarship, refers to the born person and not to the human being. ${ }^{65}$ Again, the view held above seems all the more arguable when it is considered that, under international human rights law, States are under an obligation to ensure the right to "enjoy the benefits of scientific progress and its applications" pursuant to Article 15 of the ICESCR. This provision had received little attention in the international landscape and was never recalled by international jurisprudence, neither through direct application nor as a legal support to interpretation of other clauses. ${ }^{66}$ Notwithstanding this, Article 15 of the ICESCR is widely recognized as the international legal basis of the right to science, and in 2013 the efforts of the Committee on Economic, Social and Cultural Rights focused on the draft of a General Comment on the Right to Science and to Enjoy the Benefits of Scientific Progress. ${ }^{67}$ However, while awaiting further elucidation from the Committee on Economic, Social and Cultural Rights, some guidance can be found by reference to the Travaux Préparatoires of Article 27 of the Universal Declaration of Human Rights (UDHR), ${ }^{68}$ which clarify that the language of the text of the provision "to share in scientific advancement and its benefits" is to be read in the sense of actively "participating" in scientific progress and its benefits, through reference to the verbs "participer" and "participar" respectively used in the French and Spanish version of the UDHR

65 GARCIA SAN JOSÉ, D.I., International Bio Law - An International Overview of Developments in Human Embryo Research and Experimentation, cited above n. 30, pp. 95, 96. The Charter of Fundamental Rights of the European Union makes "reference to human rights facing cloning in Article 3 (right to physical integrity) and not in Article 2 (right to life)". Therefore, it suggests that "dignity refers to a person, namely, any born person and not to the human being, like species, in the widest sense of any human life whatever conception one might have of it".

66 DONDERS, Y., "The right to enjoy the benefits of scientific progress: in search of state obligations in relation to health", see above n. 58; MANCISIDOR, M., "Is There Such a Thing as a Human Right to Science in International Law?", ESIL Reflections, n 4(1), 7 April 2015, available at http://www.esilsedi.eu/node/896 last accessed 15 October 2017. For further views and assessments on human rights in general and, in particular, on the right to science, it may also be interesting to visit the blog of Dr. Mikel Mancisidor at http://mikelmancisidor.blogspot.it/ last accessed 18 September 2017. For a wider overview, see, PETERS, A., Beyond Human Rights: The Legal Status of the Individual in International Law, Cambridge University Press, Cambridge, New York, 2016. Last but not least, it is interesting here to recall that in 2015 experts in the field of science and human rights have established the International Institute for the Human Right to Science.

67 See the Report of the Special Rapporteur in the field of cultural rights, Farida Shaheed, "The right to enjoy the benefits of scientific progress and its applications", A/HRC/20/26, Human Rigts Council, Twentieth Session, $14 \quad$ May $2012, \quad$ available at http://www.ohchr.org/Documents/HRBodies/HRCouncil/RegularSession/Session20/A-HRC-20-

26 en.pdf last accessed 14 October 2017. Following the invitation of the Special Rapporteur, the Committee on Economic, Social and Cultural Rights "kicked off" the work aimed at the adoption of a General Comment specifically dedicated to the Right to Enjoy the Benefits of Scientific Progress. See MANCISIDOR, M., "Is There Such a Thing as a Human Right to Science in International Law?", cited above n. 66.

68 UN General Assembly, Universal Declaration of Human Rights, 10 December 1948, 217 A (III), available at http://www.un.org/en/universal-declaration-human-rights/ last accessed 15 October 2017. 
(MANCISIDOR, 2015, 2). ${ }^{69}$ The reference to the Universal Declaration of Human Rights, which is recalled in the Preamble of the ICESCR and has inspired the drafting of the Covenant along with many other international human rights treaties, is beneficial to elucidate the content of States' obligations concerning the right to science and to enjoy the benefits of scientific progress and its applications", in whose scope such innovative scientific advancements as bioengineering and epigenetics can be said to fall. In this respect, therefore, it may be argued that States are under an obligation of international human rights law to ensure active participation in and enjoyment of such biotechnologies as therapeutic human somatic cells interventions and epigenetic-based diagnostic, preventive and therapeutic strategies. This appears all the more true since Article 15 of the ICESCR, going beyond Article 27 of the Universal Declaration of Human Rights, provides that States, for achieving the full realization of the right to benefits of scientific progress and its applications, have the duty to take all the necessary steps "for the conservation, the development and the diffusion of science and culture" and the obligation "to respect the freedom indispensable for scientific research and creative activity", also through "international contacts and co-operation in the scientific and cultural fields". Furthermore, postulating a human right to benefit from such innovative scientific advances as therapeutic interventions on human somatic cells and epigenetic strategies is consistent with the requirements set by Article 15 of the Oviedo Convention, that Paragraph 90 of the Explanatory Report of the Convention on Article 13 recalls as enabling conditions of human somatic cell gene therapy, and with subsequent Paragraph 95 which, when elucidating the scope of Article 15 of the Oviedo Convention, clarifies that "freedom of scientific research in the field of biology and medicine is justified [...] by the considerable progress its results may bring in terms of the health and well-being of patients". This last statement may arguably accommodate epigenetic-based diagnostic, preventive and therapeutic strategies, in line with the principle of the primacy of the human beings over the exclusive interests of science and society.

Providing accommodation for the promotion of human adaptation to climate change through a biolegal approach under international human rights law does not only mean to suggest a legal justification to this approach. It also allows to pave the way to justiciability of the violations to which individuals are victims, by enabling them to submit their complaints to international human rights bodies, either judicial or nonjudicial. This is all the more true since the Optional Protocol to the International Covenant on Economic, Social and Cultural Rights, ${ }^{70}$ entered into force in 2013, has entrusted the Committee on Economic, Social and Cultural Rights with receiving and considering

69 MANCISIDOR, M., "Is There Such a Thing as a Human Right to Science in International Law?", cited above n. 66. For deepening the analysis,also see: MORSINK, J., The Universal Declaration of Human Rights: Origins, Drafting and Intent, University of Pennsylvania Press, Philadelphia, 1999.

${ }_{70}$ UN General Assembly, Optional Protocol to the International Covenant on Economic, Social and Cultural Rights: resolution/adopted by the General Assembly, 5 March 2009, A/RES/63/117, available at http://www.ohchr.org/EN/ProfessionalInterest/Pages/OPCESCR.aspx last accessed 14 October 2017. 
communications from individuals. This new competence is likely to help enhance the further evolution of international human rights law, especially when the advances in biolaw and biomedicine are at stake, as it enables the development of the Committee's jurisprudence on the right to science and to enjoy the benefits of scientific progress.

\section{CONCLUSIONS}

"We control life, Winston, at all its levels. You are imagining that there is something called human nature which will be outraged by what we do and will turn against us. But we create human nature."

Next year, these words will celebrate their seventieth anniversary. However, there is something always very modern in the caveat by which George Orwell addressed the mankind of the second post-war back in 1948, theorizing a society where the spirit of humanity had disappeared, defeated by arrogant and arbitrary tyranny of an élite headed by the Big Brother. The masterpiece "1984" wished to exorcise several dystopic fears of those times, descending from annihilation of the essence of humanity, which in the novel is subjugated to a totalitarian political dominion through brainwashing and destruction of self-autonomy.

The fear for losing the spirit of humanity has not vanished in our modern world, otherwise occasionally it seems to be enhanced by the power of science and progress we have conquered. Not only we fear that the outstanding scientific advances now available might turn against us, but we also feel vulnerable because, in spite of this progress, still we cannot cope with many of the unprecedented challenges we are called to face.

Climate change is one of them and everyone often feels unprepared, from the international community to scientists, and individuals in their daily life. But there is still a way out of this impasse: human rights. In a world of ethical relativism, human rights are capable of embodying unifying values, as they flow from the ultimate essence of man: human dignity, a universal and absolute value. In a reality of moral pluralism, we need to reaffirm human dignity, and bioethics and biolaw offer precious guidance for this purpose. Human germline alterations and human reproductive cloning are appealing practices, but the prohibition set on them by international biolaw in both binding and nonbinding tools looks like an attempt to preserve the dominion of nature over the echo of multigenerational and transgenerational life. This prohibition is rooted in the international landscape and in numerous domestic legal orders that felt compelled to affirm it expressly. Similarly, the international community twenty years ago felt compelled to explicitly set a conventional curb in the Oviedo and to enshrine the prohibition in a legal although non-binding instrument, the UNESCO's Universal Declaration on Human Genome and Human Rights, that conveyed the consensus of almost all countries in the world. 
It is not necessary to have recourse to the 'Baxter paradox' to argue that it is still soon to claim that the prohibition of editing the genetics of future generations has become a rule of customary international law; nor it seems convincing that "cloning and inheritable genetic alterations can be seen as crimes against humanity", ${ }^{71}$ as some scholars have claimed. Nonetheless, consensus is settled and nothing suggests a shift of perspective. The view changes when we focus on therapeutic human somatic cells alterations and epigenetic-based diagnostic, preventive and therapeutic strategies, which are not at odds with the principles of international biolaw and which could benefit human health and the enjoyment of a dignified existence. When innovative practices are allowed under international law, biolaw has proven capable of promoting the affirmation of scientific progress and translating it into human rights and corresponding States duties, as it was the case for in-vitro fertilization. Indeed, sometimes some scientific advances are not immediately welcomed but receive growing acceptance in time, as it was the case for in-vitro fertilization, for example. In this regard, international bodies interpreting biolaw can play a major role for providing guidance and shedding light on viability of given biotechnological advances, especially when life is concerned. The decisions issued by the European Court of Justice with regard to patentability of parthenogenic stem cells in the cases Brüstle v. Greenpeace and International Stem Cell v. Comptroller General of Patents, Designs and Trade Marks are emblematic and are all the more interesting as they impact on a regional reality characterized by a variety of approaches. In this respect, the expression "variable geometry" by which the European landscape on research on human embryos - ranging from permissive to lacking or indirect regulation - was addressed, is emblematic. It is not unusual that international biolaw is called to bridge the gaps between quite different national views; it accounts for the flexible formulation of international biolaw instruments, which do not aim at providing definitive responses, but embrace the existing principles for providing guidance to States through implementation, respectfully of peculiar domestic ethics. Clearly, this flexible structure also allows these tools to accommodate scientific progress and the innovations it brings. One of the reasons for which biolaw can provide suitable means for fighting climate change is that it can offer innovative responses, in a field where traditional means are often outdated or inappropriate. Globalization and scientific progress, indeed, have a huge impact on climate change and new technologies, capable to innovate but at the same time to be ethical and sustainable, are welcome. The ability to reconcile scientific advances and respect for ethics is another common feature to biolaw and international responses to climate change and this helps to explain the centrality of human rights in both contexts. This also accounts for the far-sighted perspective that ensures "due regard" to "the importance of appropriate access and utilization of biological and genetic resources" and "to "the role of human beings in the protection of the environment" in the UNESCO's

71 ANNAS, G., ANDREWS, L., ISASI, R., "Protecting the endangered human: toward an international treaty prohibiting cloning and inheritable alterations", cired above n. 35 . 
Universal Declaration on Bioethics and Human Rights. This perspective addresses future generations by protecting their genetic constitution from possible adverse impact of life sciences. This is further evidence of the viability of the human rights-based model suggested by this study, which could be briefly summed up by reference to the paradigm postulated by the African Commission on Human and People's Rights in in the case Social and Economic Rights Action Center (SERAC) and Center for Economic and Social Rights (CESR) v. Nigeria, which "subscribes to a rights-based and rights-framed model of development, one in which the goal of development activities is imagined, at least in part, as the fulfilment of the economic and social rights of a people". ${ }^{72}$ This brief reference leads to the conclusive considerations, regarding the key role of States, which were appropriately defined as 'primary agents' in the realization of human rights. This is all the more true at the intersection of biolaw and climate change, where implementation of the guidance and the principles set at the international level necessarily require adequate national regulatory frameworks for enforcement. States cannot overlook that they are duty bound to protect, respect and fulfil human rights under international law, as it is the case for the right to health and the right to science and to enjoy the benefits of scientific progress, which are identified here as the suitable legal bases for accommodating the application of human somatic cells editing and epigenetics.

Conclusively, once again we can convey our view on a human rights-based approach to improve human adaptation to climate change through biolaw by recalling George Orwell's words on human nature.

Since human rights 'flow' from human dignity and convey the essence of human nature, similarly to Winston, the protagonist of '1984', we could reply to human rights sceptical by saying:

"There is something in the universe - I don't know, some spirit, some principle - that you will never overcome".

72 OKAFOR, O. K., A regional perspective: article 22 of the African Charter on Human and Peoples' Rights, in Realizing the Right to Development, Essays in Commemoration of 25 Years of the United Nations Declaration on the Right to Development, United Nations, 31 December 2013, pp. 373-384, with respect to the case 155/96 Social and Economic Rights Action Center (SERAC) and Center for Economic and Social Rights (CESR) / Nigeria, available at last accessed 17 October 2017. 


\section{BIBLIOGRAPHY}

AKEEM, A., "Genetic Engineering and Sustainable Development: A Philosophical Inquiry”, International Conference on Environmental, Biomedical and Biotechnology IPCBEE vol.41

ANNAS, G., ANDREWS, L., ISASI, R., "Protecting the endangered human: toward an international treaty prohibiting cloning and inheritable alterations", American Journal of Law and Medicine, $n^{\circ} 28 \quad(2-3), \quad 2002, \quad$ pp. 151-178.

ASHCROFT, R., "Genetic information and genetic identity", in THOMPSON, A. K., CHADWICK, R.F. (eds.), Genetic Information, Kluwer Academic, Plenum Publishing, New York, 1999.

ANDORNO, R., "Biomedicine and international human rights law: in search of a global consensus", Bulletin of the World Health Organization, $\mathrm{n}^{\circ}$ 80, 2002, pp. 959-963. ANDORNO, R., "Can human germline alterations be ethically justified?", Bioética $\begin{array}{lllll}\text { Forum, } & \mathrm{n}^{\circ} & 10 & \text { (2), } & 2017,\end{array}$ ANDORNO, R., "Dignidad Humana", Enciclopedia de Bioderecho y Bioética, available at http://enciclopedia-bioderecho.com/voces/120 last accessed 15 October 2017. ANDORNO, R., "Global bioethics at UNESCO: in defence of the Universal Declaration on Bioethics and Human Rights", Journal of Medical Ethics, n' 33 (3), 2007, pp. 150154.

ANDORNO, R., La bioética y la dignidad de la persona, Editorial Tecnos - Grupo Anaya, Madrid, 2012. ANDORNO, R., Principles of international biolaw. Seeking common ground at the intersection of bioethics and human rights, Bruylant, Bruxelles, 2013.

BINDER, G., "Cultural Relativism and Cultural Imperialism in Human Rights Law", Buffalo Human Rights Law Review, $\mathrm{n}^{\circ}$ 5, 1999, pp. 211-221.

CARDOSO RODRIGUES, R.A., 'Dos Novos Desafios À Ética, À Bioética e ao Biodireito na (Nova) Era da (R)Evolução Biotecnológica:Vias e Reflexões”, Revista Bioderecho.es, $\quad \mathrm{n}^{\circ} \quad 3, \quad 2016, \quad$ available at http://revistas.um.es/bioderecho/article/view/260451/197001 last accessed 13 October 2017.

CORTI VARELA, J. L., "Seguridad Humana ante nuevos riesgos biotecnológicos: entre la "cientificación" y la "politización"”, Araucaria. Revista Iberoamericana de Filosofía,

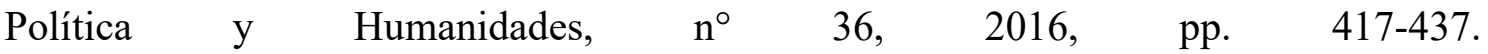


DE LA ROSA JAIMES, V., "Climate Change and Human Rights Litigation in Europe and the Americas", Seattle Journal of Environmental Law, n 5 (1), 2015, pp. 164-198.

DE MIGUEL BERIAIN, Í., JORQUI AZOFRA, M., "Patentes y biotecnología: ¿un dilema insuperable?", Anuario de filosofía del derecho, $\mathrm{n}^{\circ}$ 19, 2002, pp. 283-307.

DE SADELEER, N., "Enforcing EUCHR Principles and Fundamental Rights in Environmental Cases", Nordic Journal of International Law, $\mathrm{n}^{\circ}$ 81, 2012, 39-74.

DOLINOY, D.C., JIRTLE, R., "Environmental epigenomics in human health and disease", Environmental and Molecular Mutagenesis, $n^{\circ}$ 49(1), January 2008, pp. 4-8.

DONDERS, Y., "The right to enjoy the benefits of scientific progress: in search of state obligations in relation to health", Medicine, Health Care, and Philosophy, ${ }^{\circ}$ 14(4), November 2011 ,

pp.

$371-381$.

ESER, A., "Perspectives of medical law under the auspices of modern biotechnology"; Revista de Derecho y Genona Humano, Numero Extraordinario, 2014, pp. 87-101.

FEITO GRANDE, L., "Ingeniería genética (Ético)”, ENCICLOPEDIA de BIODERECHO y BIOÉTICA, available at $\mathrm{http}: / /$ enciclopediabioderecho.com/voces/185 last accessed 15 October 2017.

FRETWELL WILSON, R., "The Death of Jesse Gelsinger: New Evidence of the Influence of Money and Prestige in Human Research", American Journal of Law \& $\begin{array}{lllll}\text { Medicine, } & \mathrm{n}^{\circ} & 36, & 2010, & \text { pp. }\end{array}$

GARCÍA SAN JOSÉ, D.I., Crisis económica, vulnerabilidad multidimensional y cambio climático: la "tormenta perfecta" para el derecho a la salud en europa, Bioderecho.es, Estudios de Vulnerabilidad, n. 5, 2017, available at http://revistas.um.es/bioderecho/article/view/290821 last accessed 10 October 2017. GARCÍA SAN JOSÉ, D., "Derecho de la Unión, Investigación Embrionaria Humana y Patentes Biológicas", Revista de Derecho Comunitario Europeo, n 41, Enero-Abril 2012 , pp. 161-180. GARCÍA SAN JOSÉ, D., "Epigenética y gestación por sustitución: más razones a favor de una regulación internacional para un negocio global", Anuario Mexicano de Derecho $\begin{array}{lllll}\text { Internacional, } & \text { vol. } & \text { XVII, } & \text { 2017, } & \text { pp. }\end{array}$

GARCÍA SAN JOSÉ, D.I., International Bio Law - An International Overview of Developments in Human Embryo Research and Experimentation, Ediciones Laborum, 
Murcia,

2010.

GROSS ESPIELL, H., "La Dignidad Humana en los Instrumentos Internacionales sobre Derechos Humanos", Anuario de Derechos Humanos. Nueva Época, n 4, 2003, pp. 193 223.

GUERRERO-BOSAGNA C., JENSEN, P., "Globalization, climate change, and transgenerational epigenetic inheritance: will our descendants be at risk?", Clinical $\begin{array}{lllll}\text { Epigenetics } & \mathrm{n}^{\circ} & 7(1), & \text { 2015, } & \text { 8-13. }\end{array}$

GUNDERSON, M., "Enhancing Human Rights: How the Use of Human Rights Treaties to Prohibit Genetic Engineering Weakens Human Rights", Journal of Evolution and $\begin{array}{llllll}\text { Technology, } \quad \mathrm{n}^{\circ} & \text { 18(1), } & \text { May } & \text { 2008, }\end{array}$

HAIJKOVA P., "Epigenetic reprogramming of the germline: towards the ground state of the epigenome", Philosophical Transaction of the Royal Society, $n^{\circ} 366,2011$, pp. 22662273.

HANSELL, G.L., H+/-: Transhumanism and Its Critics, Metanexus, Philadelphia, 2011.

HAREES, L., The Mirage of Dignity on the highways of Human 'Progress': the bystanders' persepctive, Authorhouse, Bloomington, 2012

HERRERA FLORES, J., Los derechos humanos como productos culturales: Crítica del humanismo abstracto, Catarata, Madrid, 2005.

HILDT, E., "Human Germline Interventions-Think First", Frontiers in Genetics, ${ }^{\circ} 7$, $\begin{array}{llll}\text { Article } & \mathrm{n}^{\circ} & 816 .\end{array}$

HIPP, J., ATALA, A., "Tissue engineering, stem cells, cloning, and parthenogenesis: new paradigms for therapy", Journal of Experimental and Clinical Assisted Reproduction, $\mathrm{n}^{\circ}$ 1(3), 2004, available at https://www.ncbi.nlm.nih.gov/pmc/articles/PMC539246/pdf/1743-1050-1-3.pdf last $\begin{array}{llll}\text { accessed } & 14 & \text { October } & 2017 .\end{array}$

JI, H., KHURANA HERSHEY G.K., "Genetic and epigenetic influence on the response to environmental particulate matter", Journal of Allergy and Clinical Immunology, $\mathrm{n}^{\circ}$ 129(1), January 2012, PP. 33-41.

KEIL K.P., LEIN, P.J., "DNA methylation: a mechanism linking environmental chemical 
exposures to risk of autism spectrum disorders", Environmental Epigenetics, $n^{\circ} 1,2015$, available at https://academic.oup.com/eep/article/2/1/dvv012/2464729 last accessed 13 October

KIM, J., "Regulating Economic Development: Environmental and Social Standards of the AIIB and the IFC", Harvard Journal of International Law, 21 April 2016. available at http://www.harvardilj.org/2016/04/regulating-economic-development-environmentaland-social-standards-of-the-aiib-and-the-ifc/ last accessed 12 October 2017.

KLITZMAN, R., ““'Am I my genes?”: Questions of identity among individuals confronting genetic disease", Genetics in Medicine, $\mathrm{n}^{\circ}$ 11(12), December 2009, pp. 880889.

LIAO, M., SANDBERG, A., ROACHE, R., 'Human Engineering and Climate Change', 2012. Forthcoming as a Target Article in Ethics, Policy and the Environment, available at http://www.smatthewliao.com/wpcontent/uploads/2012/02/HEandClimateChange.pdf last accessed 7 October 2017.

LOCKYER, E.L., "The potential of CRISPR-Cas9 for treating genetic disorders", Bioscience Horizons, $\mathrm{n}^{\circ}$ 9, 2016, available at https://academic.oup.com/biohorizons/article/doi/10.1093/biohorizons/hzw012/2562795 $\begin{array}{lllll} & \text { last } & 7 & \text { Occessed } & \end{array}$

MANCISIDOR, M., "Is There Such a Thing as a Human Right to Science in International Law?", ESIL Reflections, $n^{\circ}$ 4(1), 7 April 2015, available at http://www.esil$\begin{array}{lllll}\text { sedi.eu/node/896 last } & \text { accessed } & 15 & \text { October } & 2017 .\end{array}$

MARIS MARTÍNEZ, S., "Ingeniería genética (Jurídico)”, ENCICLOPEDIA de BIODERECHO y BIOÉTICA, available at http://enciclopediabioderecho.com/voces/186 last accessed 15 October 2017.

MARKS, S. P., "Tying Prometheus Down: the International Law of Human Genetic Manipulation", Chicago Journal of International Law 3 (1), 2002, pp. 115-136. MAZZONI, M., RODOTà, S., ZATTI, P., Trattato Di Biodiritto. Il governo del Corpo, GIUFFRé, Milano,

2011.

McADAM, J., "Part IV, Living with climate change and climate change adaptation measures - CH. 23 Climate change and related displacement of persons" in CARLARNE, C.P., GRAY, K.R., TARASOFSKY, R., (eds.), Oxford Handbook of International Climate Change Law, Oxford University Press, Oxford, 2016. 
McLEAN, S.A.M., Genetics and Gene Therapy, Routledge, London, 2017.

MORELLI, M., "El concepto del bioderecho y los derechos humanos", Vida y Ética, ${ }^{\circ}$ 1, año $\quad 11, \quad 2010, \quad$ pp. $194-222$.

MORSINK, J., The Universal Declaration of Human Rights: Origins, Drafting and Intent, $\begin{array}{llll}\text { University of } & \text { Pennsylvania }\end{array}$

MUYARADZI, M., "Critical reflections on the principle of beneficence in biomedicine", Pan African Medical Journal $\mathrm{n}^{\circ}$ 11(29), 2012, available at https://www.ncbi.nlm.nih.gov/pmc/articles/PMC3325067/pdf/PAMJ-11-29.pdf last $\begin{array}{llll}\text { accessed } & 7 & \text { October } & 2017\end{array}$

NICKEL, J., REIDY, K., Relativism, Self-Determination, and Human Rights, available at http://web.utk.edu/ dreidy/nickelreidyfinaldraft2005.pdf last accessed 11 October 2017.

NICKEL, J. W., Making sense of human rights: Philosophical reflections on the universal declaration of human rights, University of California Press, Berkeley, 1987.

NUEVO LÓPEZ, P., "Dignidad humana y patentabilidad de invenciones biomédicas", Estudios de Deusto, $\mathrm{n}^{\circ} \quad 60 \quad$ (1) (2012), pp. 327-355.

OBASOGIE, O. K., “Ten Years Later: Jesse Gelsinger's Death and Human Subjects Protection", The Hastings Center, availbale at http://www.thehastingscenter.org/tenyears-later-jesse-gelsingers-death-and-human-subjects-protection/ last accessed 15 October 2017.

OKAFOR, O. K., A regional perspective: article 22 of the African Charter on Human and Peoples' Rights, in Realizing the Right to Development, Essays in Commemoration of 25 Years of the United Nations Declaration on the Right to Development, United Nations, 31 December 2013, pp. 373-384.

ORMOND, K.E., MORTLOCK, D.P., SCHOLES, D.T., BOMBARD, Y., BRODY, L.C., FAUCETT, A., GARRISON, N.A., HERCHER, L., ISASI, R., MIDDLETON, A., MUSUNURU, K., SHRINER, D., VIRANI, A., YOUNG, C.E., "Human Germline Genome Editing", The American Journal of Human Genetics, n 101 (2), 3 August 2017, pp.

167-176.

PALLADINO, M.A., Understanding the Human Genome Project, Benjamin Cummings, 
PASQUALUCCI, J., "The Right to a Dignified Life (Vida Digna): The Integration of Social and Economic Rights with Civil and Political Rights in the Inter-American Human Rights System”, Hastings International and Comparative Law Review, n 31(1), 2008, pp.

PETERS, A., Beyond Human Rights: The Legal Status of the Individual in International Law, Cambridge University Press, Cambridge, New York, 2016.

RODOTA', S., La Vita e le Regole. Tra Diritto e Non Diritto, laFeltrinelli, Milano, 2006.

SÁNCHEZ PATRÓN, J. M., TORRES CAZORLA, M.I., GARCÍA SAN JOSÉ, D., Bioderecho, Seguridad y Medioambiente. Biolaw, Security and Environment, Tirant Lo Blanch, Valencia,

2015.

SHEARD, A., "Patenting Stem Cell Technologies in Europe", Cold Spring Harbour Perspective in Medicine, $n^{\circ}$ 5(3), March 2015, available at last accessed 20 October 2017.

SHUKLA, S., MEERAN, S.M., KATIYAR, S.K., "Epigenetic regulation by selected dietary phytochemicals in cancer chemoprevention", Cancer Letters, $n^{\circ} 355(1), 1$ December 2014, pp. 9-17.

SMITH, K.R., "Gene Therapy: The Potential Applicability of Gene Transfer Technology to the Human Germline", International Journal of Medical Science, n 1(2), 2004, pp. 7691.

SPAAK, T., "Moral Relativism and Human Rights", Buffalo Human Rights Law Review, Vol. 13, 2007, available at https://papers.ssrn.com/sol3/papers.cfm?abstract_id=923445 last accessed 7 October 2017.

SPEAKER, S. L., LINDEE, M. S., HANSON, E., A Guide to the Human Genome Project: Technologies, People, and Institutions, Chemical Heritage Foundation, Publication $n^{\circ} 11$, Philadelphia,

1993.

STILLINGS, Z. L., "Human Rights and the New Reality of Climate Change: Adaptation's Limitations in Achieving Climate Justice", Michigan Journal of International Law, $\mathrm{n}^{\circ}$ $35(3)$ 2014 , pp. 638-671.

TOMPKINS, J.D., HALLC, C., CHENC V.C.-Y., XUEJUN LIE, A., WUE, X., HSUC, D., COUTUREC, L.A., RIGGSA, A.D., "Epigenetic stability, adaptability, and 
reversibility in human embryonic stem cells", PNAS, n 109 (31), 31 July 2012, available at http://www.pnas.org/content/109/31/12544.full.pdf last accessed 15 October 2017.

VALLERO, D.A., Environmental Biotechnology: A Biosystems Approach (Elsevier, 2nd Ed.,

VIDAS, D., "The Earth in the Anthropocene and the World in the Holocene?", ESIL Reflections, 24 August 2015, 4(6), available at http://www.esil-sedi.eu/node/987 last accessed

VOGT, G., "Facilitation of environmental adaptation and evolution by epigenetic phenotype variation: insights from clonal, invasive, polyploid, and domesticated animals", Environmental Epigenetics, $\mathrm{n}^{\circ}$ 3(1), 2017, pp. 1-17.

WEINHOLD, B., "Epigenetics: the science of change", Environmental Health Perspectives, ${ }^{\circ}$ 114(3), March 2006, A160-A167. 